\title{
ARISTOTLE, HIS COURSE ON NATURAL PHILOSOPHY AND THE ARABIC TRADITION
}

\author{
JOSEP PUIG MONTADA \\ UNIVERSIDAD COMPLUTENSE/MARQUETTE UNIVERSITY
}

\begin{abstract}
The article consists of three parts. The first examines the Arabic translations of Aristotle's Physics; the second analyses the history of the translation by Ishāa Ibn Hunayn, that is the only extant and was subject to various commentaries; and the third focuses on the beginning of Book VII. There are two versions of the Greek text for this passage, and there is evidence that Ishāq Ibn Ḥunayn relied on a text closer to $\beta$-version for his translation.
\end{abstract}

\section{Key Words}

Greek into Arabic, Isḥāq Ibn Ḥunayn, Aristotle's Physics, Versions $\alpha$ and $\beta$ of the beginning of Physics VII.

I

In contrast to its attitude towards Plato's works, the Arab world was very receptive to those of Aristotle. Not only was Aristotle's corpus translated into Arabic but many Greek commentaries-among them, those of Alexander of Aphrodisias, Themistius and John Philoponus-were so appreciated, that they were appended to many of the translations. ${ }^{1}$

The Arabic listings of scholars, their lives and works provide us with quite accurate information about the Arabic translations. The oldest history of this genre, by Abū l-Faraj Muhammad ibn Ishạā [Ibn] al-Nadīm (d. 990) comprehends

1 I am much obliged to Prof. Owen Goldin, Marquette, for editing the English. Of course, all remaining errors are my own. 
the masters of the sciences of the Koran, including grammarians, historians, poets, and jurists, as well as of the sciences of the Ancients, on which there is a chapter on Aristotle. ${ }^{2}$ There he explains Aristotle's life and works. The book was translated into English by Bayard Dodge. ${ }^{3}$ When Ibn al-Nadīm comes to Aristotle's Physics, he names it al-Samā' al-Tabìi ('Natural Hearing'), 'The Course on Natural Philosophy', which is the literal translation of $\Phi v \sigma i k \dot{\alpha} \alpha \kappa \rho o ́ \alpha \sigma \iota s$, and mentions three Arabic versions that included commentaries as well: ${ }^{4}$

(A) Treatise on the Hearing of the Physics. With the commentary by Alexander [of Aphrodisias], eight books. Muhammad Ibn Ishāq [Ibn al-Nadīm] says that following commentaries by Alexander of Aphrodisias are found:

[Alexander commented on] Aristotle's First Book in two volumes, the first and part of the second of which are extant. Abū Rawh the Sabean [al-Șābi'] translated it and Yahyā Ibn 'Adī corrected the translation. Aristotle's Second Book in one volume; Hunayn translated it from Greek into Syriac and Yahyā Ibn 'Adī from Syriac into Arabic. [Alexander's] commentary on Book III of Aristotle is not extant. He commented on Book IV in three volumes, the first and the second are extant, as part of the third, up to the treatise on time. Qusța translated it [but] al-Dimashqî̀s translation that has been kept is the known one. [His commentary on] Book V exists in one volume, translated by Qusțā Ibn Lūqā. Book VI is one volume, a little over half of which is extant. Book VII is one volume, which Qusța translated. Book VIII is one volume, only a few leaves of which exist. ${ }^{5}$

(B) Treatise on the Hearing of the Physics, with the Commentary of Yahyā al-Nahwī [John Philoponus] of Alexandria:

The part of this book which Qusțā [Ibn Lūqā] translated is in the form of lessons (ta'ālìm), but that part which Ibn Nā'ima ['Abd al-Masìh] translated is not. Qusțâ translated the first half, which is in four volumes, and Ibn Nā'ima the last second half, which is the other four volumes.

Ta'âlim plural of ta'lim likely expresses a didactical way of organizing Aristotle's text.

Abū l-Faraj Muhammad Ibn al-Nadīm, Kitāb al-Fihrist li-l-Nadīm, ed. Reza Tajaddud, Teheran: Marvi Offset Printing, 1971, pp. 307-323.

3 Id., The Fihrist of al-Nadim, trans. Bayard Dodge, New York: Columbia University, 1970, pp. 594606.

4 Ibn al-Nadīm, Kitāb al-Fihrist li-l-Nadìm, pp. 310-311. The English translation is mine.

5 Id., The Fihrist of al-Nadim, pp. 602-603. Bayard Dodge observes that the passage is confused, because the word al-maqāla is used both to refer to the original eight books of Aristotle's Physics and also to the parts or volumes of the commentary. 
Aristotle, his Course on Natural Philosophy and the Arabic Tradition

(C) Treatise on the Hearing of the Physics, with commentaries of various philosophers.

[According to Abū 'Alī] Porphyry's commentary on the first, second, third, and fourth Books is extant. Basīl translated it. Abu Bishr Mattā wrote a commentary in Syriac of Themistius' commentary on this book. Part of Book I in Syriac is extant. Abu Hāmid Ibn Karnīb wrote a commentary on part of the Book I and part of Book IV, as far as the discourse on time. Thābit ibn Qurra produced a commentary on part of the first section, while [Abū 'Alī] Ibrahīm ibn al-Șalt translated the first section of this book. I saw it written in the handwriting of Yahyā ibn 'Adī. Abū alFaraj Quddāma ibn Ja'far ibn Quddāma also wrote a commentary on part of Book I of the Hearing of the Physics.

The Fihrist provides biographical information of most of the aforementioned translators and commentators; indeed, these biographies constitute a helpful source for our understanding of the process of translation:

(A) Those involved in the Physics with the commentary by Alexander of Aphrodisias (fl. $200 \mathrm{CE}$ ), who became head of the Peripatetic school at Athens, are the following:

Abū Rawh the Sabean was a secretary of 'Alī Ibn 'Īsā Ibn al-Jarrāḥ (d. 946), vizier of the caliph al-Muqtadir (r. 908-929). ${ }^{6}$

Yahyā Ibn 'Adī (d. 974), a disciple of Abū Bishr Mattā (d. 940), he was a Jacobite Christian, translator, commentator and apologetic philosopher. ${ }^{7}$

Hunayn [Ibn Ishāq al-'Ibādī] (d. 873) is the well-known translator of Galen, mainly of his medical works, from Greek into Syriac. He was a Nestorian Christian physician who moved to Baghdad at the time of the caliph al-Ma'mūn. ${ }^{8}$

Qusțā [Ibn Lūqā al-Ba'albakī, d. 912], a Melchite Christian, from Syria; he was a physician and translator. ${ }^{9}$

[Abū 'Uthmān] al-Dimashqī (d. post 914) again a physician and translator; he enjoyed the patronage of 'Alī Ibn 'I'sā Ibn al-Jarrāḥ, the aforementioned vizier.

(B) The one involved in the Physics with the commentary by Yahyā al-NahwīYahyā al-Nahwī is the Arabic name of John the Grammarian, John Philoponus, (d. ca. 575), one of the most influential late Greek philosophers; he was a Christian Nestorian who commented on Aristotle and argued against his doctrine of the eternity of the world:

6 My information comes from Francis Peters, Aristoteles Arabus: The Oriental Translations and Commentaries of the Aristotelian Corpus, Leiden: Brill, 1968, p. 34.

Ibn al-Nadīm, Kitāb al-Fihrist li-l-Nadìm, p. 322.

8 Ibid., pp. 352-353.

$9 \quad$ Ibid., p. 353. 
Ibn Nā'ima al-Himșī, a Christian from Syria (fl. c. 835) belongs to the so-called al-Kindì's circle, and therefore, to the first stage of translations. The Muslim philosopher al-Kindī (c. 800-870) was close to the Abbasid caliph al-Mu'tașim. ${ }^{10}$

(c) Those involved in the third translation of the Physics with 'commentaries of various philosophers'-two Greek commentators are mentioned among them: Porphyry (d. c. 305 CE), the disciple of Plotinus, and Themistius (d. c. 387), also a Neo-Platonist:

Basīl, Basilios, is no doubt a Christian, and Peters links him to Hunayn's circle. ${ }^{11}$

Abū 'Alī could be Abū 'Alī al-Jubbā'̄i, a Mu'tazilite mutakallim, whose death occurred in $916 ;{ }^{12}$ he cannot be the philosopher Abū 'Alī Ibn al-Samh (d. 1027), who was biographized by Miklos Stern, ${ }^{13}$ because Ibn al-Nadìm had died in 990 CE.

Ibn Karnīb, Abū Ahmmad al-Ḥusayn ibn Abī al-Ḥusayn Ishạâ, is also a mutakallim ${ }^{14}$ and since he wrote a treatise against Thābit Ibn Qurra regarding his views on motion and rest, we can assume that he belonged to the Mu'tazilite school. Dodge translates 'He was one of the most eminent of the theologians, upholding the doctrines of the natural philosophers'. ${ }^{15}$

Thābit Ibn Qurra (d. 901), the Sabaean astronomer, is not biographized by Ibn al-Nadim; nevertheless, he is often quoted in the Fihris.

[Abu Nūh] Ibrāhīm Ibn al-Ṣalt lived in the ninth century, and translated into Syriac and Arabic. He is credited with the translation of Ptolemy's Tetrabiblos 'that Hunayn Ibn Ishāq revised' and some of Galen's medical writings.

Abū l-Faraj Quddāma (d. 948) was close to the vizier al-Faḍl ibn al-Furāt (d. 938). The vizier Fadl had converted to Islam from Zoroastrianism and entered the service of the caliph Hārun al-Rashid and his son al-Ma'mūn. Abū l-Faraj Quddāma converted to Islam under the sponsorship of the caliph al-Muktafì biAllāh (902-908). ${ }^{16}$

The three translations with their commentaries belong to three stages. Translation (B) belongs to the earliest stage, within al-Kindi's circle in the eight century; (A) follows, being related to Hunayn Ibn Ishāa, founder of a school; (C) is close to (A) insofar as Basill was a disciple of Hunayn. What we see is that while

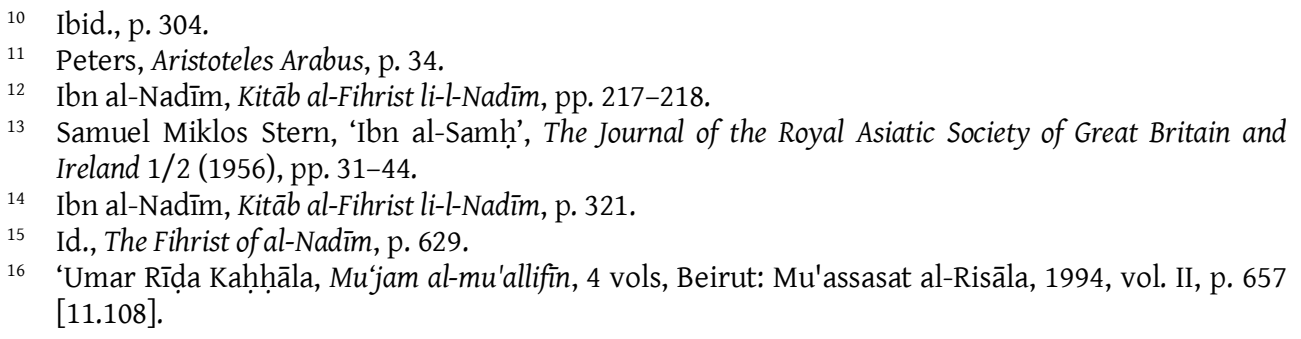


Aristotle, his Course on Natural Philosophy and the Arabic Tradition

difficulties in a translation might have been the cause for making a new one, more significantly, the need for commentaries was an incentive for new translations.

After Ibn al-Nadīm we should turn to Ibn al-Qifți (d. 1248), who basically repeats him but adds some observations, for instance, about the title: he mentions that the work is also known as Sam' al-Kiyān, calque of the Syriac šem ' $\bar{a}$ $k y \bar{a} n \bar{a} y \bar{a}^{17}$ or that Abu Rawh the Sabean was translating from Syriac. When reporting on Yahyā al-Nahwīi [John the Grammarian], Ibn al-Qifțī writes:

Yahyāa al-Nahwī commented [on the Physics] and [his commentary] was translated from Greek into Arabic. It is a large work and once I had it in my hands. It makes ten volumes; Jūrjīs al-Yabrūdī added marginal notes he took from Themistius. The volumes belonged to 'Īsā, the son of the vizier 'Alī Ibn 'Tsā Ibn al-Jarrāh. ['Tsā] read them to Yahyā Ibn 'Adī and added marginal notes containing useful observations made by Yahyā, while he was reading to him. [Yahyā al-Naḥwī's] wording is best in quality and clarity. ${ }^{18}$

We have already encountered 'Alī Ibn 'Īsā Ibn al-Jarrāḥ: he was the vizier of the caliph al-Muqtadir, and also the patron of Abū Rawh the Sabean and of Abū 'Uthmān al-Dimashqī, and now we read that his son was a disciple of Yahyā Ibn 'Adī. No doubt both Yahyyā's-Yahyā al-Naḥwī and Yahyā Ibn 'Adī-played a key role in the transmission of Aristotle's Physics. While John the Grammarian was essential in the interpretation of the book, the latter was very influential in spreading the Physics in the Abbasid milieu.

Another observation that we should not neglect concerns the Syriac contribution to the study and translation of the Physics. In two places Ibn alNadim points to the Syriac tradition: For (A) 'Hunayn translated it from Greek into Syriac and Yahyā Ibn 'Adī from Syriac into Arabic', and for (C) 'Abu Bishr Mattā wrote a commentary in Syriac of Themistius' commentary on this book. Part of Book I in Syriac is extant'. ${ }^{19}$ Yury Arzhanov and Rüdiger Arnzen have authored a very thorough research paper, in which they highlight the Syriac contribution; ${ }^{20}$ we shall return to them later.

17 'Alī Ibn Yūsuf al-Qifțī, Ta'rīkh al-Ḥukamā', ed. Julius Lippert and August Müller, Leipzig: Dieterich'sche Verlagsbuchhandlung, 1903, p. 38.

8 al-Qifțī, Ta'rïkh al-Hukamā', p. 39.

19 Ibn al-Nadīm, Kitāb al-Fihrist li-l-Nadìm, pp. 310-311.

20 Rüdiger Arnzen and Yury Arzhanov, 'Die Glossen in Ms. Leyden Or. 583 und die syrische Rezeption der aristotelischen Physik', in Elisa Coda and Cecilia Martini Bonadeo (eds), De l'antiquité tardive au Moyen Âge: études de logique aristotélicienne et de philosophie grecque, syriaque, arabe et latine offertes à Henri Hugonnard-Roche, Paris: Vrin, 2014, pp. 415-464 
Not one of the translations with commentaries on which Ibn al-Nadim reported is extant. By contrast a translation by Ishāq Ibn Hunayn is preserved in a manuscript of the Warner collection n. 583, in Leiden; ${ }^{21}$ 'Abd-ar-Rahmān Badawi edited it in 1959. ${ }^{22} \mathrm{Abu}$ Ya'qūb Ishạq Ibn Hunayn (d. c. 910-911) was the son of the aforementioned Hunayn and translated philosophy from Greek into Arabic. ${ }^{23}$

The Leiden colophon reads that the copy was finished in Baghdad on $1^{\text {st }}$ of Dhu l-Qa'da $524 \mathrm{H}$, equivalent to 6 October $1130^{24}$ but the colophon is not the only place where information on the translation is given.

At the end of Book I we find following account:

The first book has ended. Translation by Ishāq Ibn Ḥunayn, praise be to God who deserves all praise. [The copy] was finished in Khuzistān, in Qașr [Rūnash] on $1^{\text {st }}$ of Șafar de 524 of the Hegira (14 January 1130).

[On the left margin:] It has been collated, praise be done to God.

[On the right margin:] Handwritten notice of the sheikh Abu l-Husayn (Muhammad Ibn 'Alī al-Bașrī): 'I finished copying and commenting on it in the month of Șafar 395 Hegira (November 1004)'.

[On the left margin:] Written in his own hand, on the title-side of the first and second part: ${ }^{25}$ 'I collationed ('áradtu) this part of the text with the copy of Yahyā Ibn 'Adī, who says that he copied it from the original text of Ishāa Ibn Hunayn, and that he collationed it three times, and even a fourth time when he collationed it with the Syriac text. Those amendments and marginal glosses marked by 'hāa' belong to Yahyā's copy'.

[On the title-page of the first part:] First part of Aristotle's Physics Hearing. Translation by Isḥāq Ibn Ḥunayn, it contains a commentary by Abī l-Ḥasan Ibn alSamh. [Abū l-Husayn] Muḥammad Ibn 'Alī al-Bașrī followed it ('aliqa 'anhu).

He added 'words of Mattā' to the title-page of the third part, 'words of Abū Bishr Mattā' to the title-page of the fourth part, and 'words of Yahyā' and 'words of Abū Bishr Mattā' to the title-page of the fifth part.

Abū l-Hakam remarked: 'This is all I have transmitted according to what is written in the original copy from which I copied it in Karkh, Jumādā II 470 [December 1077].' I changed only the date as it is the one appropriate to this

21 Pieter De Jong and Michael Jan de Goeje, Catalogus codicum orientalium bibliothecae Academiae Lugduno Batavae, vol. III, Leiden: Brill, 1865, pp. 310-312.

22 Arisțūțāl̄̄s, Al-Ṭabîa [henceforth, Al-Ṭabîa], ed. 'Abd-ar-Rahmān Badawi, Cairo: Al-Hay'a alMișrìya al-'Āmma li-l-Kitāb, 1965.

23 Ibn al-Nadīm, Kitāb al-Fihrist li-l-Nadīm, p. 356.

$24 \quad$ Al-Ṭabìa, p. 937.

25 I literally translate juz' as 'part.' Stern translated juz' as 'fascicle' and Giannakis preferred the term 'quire'. Giannakis says that the codex consisted of twenty-two unbound quires; see Elias Giannakis, Philoponus in the Arabic Tradition of Aristotle's Physics, Oxford: British Thesis Service, 1992, pp. 23-27. 
Aristotle, his Course on Natural Philosophy and the Arabic Tradition

copying. I neither added nor removed any single letter. Who reads my text is like one who reads the original one which was copied from the translator's own copy. ${ }^{26}$

The copyist was careful to write down the place and the date when he finished any book, and when it came to Book II, he wrote: 'The copy was finished in Jundī Shābūr, in the Khuzistān, on $22^{\text {nd }}$ of Șafar $5244^{\prime}{ }^{27}$

When he completed the copy of Book III, he wrote: 'Copying was carried out in Rabī' I in 'Askar Makram', a place again in the Khuzistān' .

In the colophon of Book IV, we read: 'The commentary ( $t a{ }^{\prime}$ liq $)$ on Book IV of the Physics Hearing by the sheikh the imam the sage Abū l-Husayn Muhammad Ibn 'Alī al-Bașrī ended. Praise be given to God. The copy was finished on the last day of Rajab 524 in Baghdad'. ${ }^{29}$ A marginal gloss states here: 'It was compared ( $q \bar{u}$ bilat) with God's help, may He be praised'. ${ }^{30}$

At the end of Book V, the copyist wrote: 'Copying ended on $20^{\text {th }}$ of Sha'bān in Baghdad. Abū l-Hakam al-Maghribī made it for himself. ${ }^{31}$ It is not clear whether the nisba is al-Maghribī or al-Ma'arrī, as Badawi prints it, since the manuscript is not decisive to my view. ${ }^{32}$

At the end of Book VI, another marginal gloss reminds: '[The copy] was compared (qübilat) with the original with God's praise in the month of Shawwāl $524^{3} .^{33}$

At the end of Book VII, the information reads: 'The commentary was completed, praise to be done to God the One and prayers for Muhammad the prophet of the Compassionate and peace'34 and on the margin: 'It was compared'. ${ }^{35}$

The copyist is not mentioned at the end of Book VIII; however, the other annotations give us significant information about his activity: Abū l-Hakam spent almost one year with copying, since he started on $1^{\text {st }}$ of Șafar 524 Hegira (14 January 1130) and he finished on $1^{\text {st }}$ of Dhū l-Qa'da 524 (6 October 1130).

We are informed also about the places of his work: Khuzistān or Khuzestan, Karkh (Baghdad's quarter on the West side of the Tigris), Jundī Shābūr (also in Khuzestan, the town was founded by the Sāsānian king Shāhpūr [240-270 CE]), 'Askar Makram (Khuzestan), and Baghdad. Khuzestan was the region between the

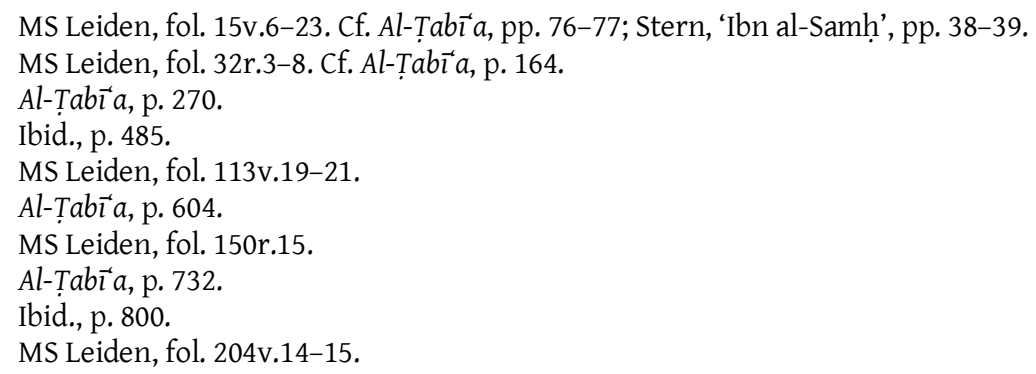


lower course of the Tigris and its joint estuary with the Euphrates, the Shat elArab, on the southwest, the head of the Persian Gulf, on the South, and the Zagros Mountains, on the northeast.

The Seljuq sultans of Hamadan exercised a kind of guardianship over the Abbasid caliph sitting in Baghdad. The Seljuq sultan Mahmūd II (d. 1131) ruled over Southern Iraq and Khuzestan during the caliphate of al-Mustarshid (512529/1118-1135), ${ }^{36}$ so that when Abu l-Hakam worked on copying the manuscript in the year 524/1030 he could have been an officer in the service of Mahmūd II, as data elsewhere confirm.

In his article on Ibn al-Samh, Miklos Stern gives us adequate information about him, which he had gathered from the classical bio-bibliographies. ${ }^{37} \mathrm{Abu}$ lHakam's full name was Abū l-Ḥakam 'Ubayd Allāh ibn al-Muzaffar bn 'Abd Allāh al-Bāhilī, surnamed Tāj al-Hukamā’; his family was originally from Almeria. He himself was born in the Yaman in 486/1093-1094. He worked for a financial administrator (mustawfï) of Sultan Mahmūd called al-'Azìz. When this mustawfi fell into disgrace, Abu l-Hakam left Iraq and settled in Damascus. He died in that city on the $4^{\text {th }}$ of Dhü l-Qa'da 549 (10 January 1155).

On the basis of the information supplied by the colophons, we can determine that the Leiden manuscript contains the translation by Ishāq Ibn Hunayn (d. c. 910911) as its main body; the translation was commented on by Ibn al-Samh (d. 1027), a representative of the school of Yahyā Ibn 'Adī, and others. It was compared with another manuscript and the variants are indicated by the siglum $h \bar{a}$ '. They belong to the copy owned by Yahyā Ibn 'Adī (d. 974) which should be also the very translation made by Ishāq Ibn Hunayn. Abū Ya'qūb Ishāq Ibn Hunayn was Hunayn's son and translated philosophy from Greek into Arabic, for which Ibn al-Nadìm honored him in his work. ${ }^{38}$

Abū l-Ḥusayn Muhammad Ibn 'Alī al-Bașrī appears in the context as the man who really did the critical edition, while Abū l-Hakan was the faithful and reliable copyist. Who was then Abū l-Husayn al- Bașrī?

Stern searched for him in the biographical dictionaries and theological writings, and he identified him as Abū l-Husayn (or Abū l-Hasan) Muhammad ibn 'Alī ibn al-Ṭayyib al-Bașrī. He was born in Basra and studied in Baghdad with Abū 'Alī Ibn al-Samh. Abū l-Ḥusayn was also an outstanding Mu'tazilite. He passed away on $5^{\text {th }}$ of Rabi' II 436 (30 October 1044), in Baghdad. ${ }^{39}$ Wilferd Madelung ${ }^{40}$

36 Clifford Edmund Bosworth, 'The Political and Dynastic History of the Iranian World (10001217)', in John Andrew Boyle (ed.), The Cambridge History of Iran, Cambridge: Cambridge University Press, 1968, pp. 119-124.

37 Stern, 'Ibn al-Samh', pp. 34-36.

38 Ibn al-Nadīm, Kitā̄b al-Fihrist li-l-Nadīm, p. 356.

39 Stern, 'Ibn al-Samh', pp. 36-38. 
Aristotle, his Course on Natural Philosophy and the Arabic Tradition

adds that Abū l-Ḥusayn al- Bașrī was a student of the great Qādī 'Abd al-Jabbār (d. 1025), who systematized the Mu'tazilite doctrines. Giannakis remarks that he was also a disciple of Abu l-Faraj ibn al-Tayyib, who was his contemporary; he passed away one year before Abū l-Husayn. ${ }^{41}$

His edition of the Physics is dated 1004 and in Baghdad, therefore its time and place match to his lifespan. Abū l-Ḥusayn al-Bașrī did not know Greek as Ibn Nā'ima (fl. c. 835) and the first generation of translators did, but he mastered Syriac. Emilio Platti describes his edition as 'a classical instance of a critical edition in the school of Yahyā Ibn 'Adī' ${ }^{42}$ And actually, the Leiden manuscript shows a long tradition of scholarship:

(1) The main body is made by the translation of Ishāq Ibn Ḥunayn, following the recension of Ibn al-Samh (d. 1027).

(2) It was compared with the copy owned by Yahyā Ibn 'Adī (d. 974), and variants are indicated with the siglum H. 57 (marginal notes have that mark).

(3) Comments ascribed to Alexander of Aphrodisias (fl. $200 \mathrm{CE}$ )

(4) Comments ascribed to Themistius (d. 387)

(5) Comments ascribed to John the Grammarian (d.c. 570)

(6) Comments ascribed to Abū Bishr Mattā (d. 940)

(7) Comments ascribed to Yahyā Ibn 'Adī (d. 974)

(8) Comments ascribed to Abū 'Alī Ibn al-Samh (d. 1027)

(9) Comments ascribed to Abū l-Faraj Ibn al-Ṭayyib (d. 1043)

(10) Rand glosses by Abū l-Ḥusayn Muhammad Ibn ‘Alī al-Bașrī (d. 1044).

A few remarks should be made in regard to the list above:

(a) Elias Giannakis wrote his PhD dissertation at Oxford University (1992) with the title 'Philoponus in the Arabic tradition of Aristotle's Physics'. The first part studies de Leiden manuscript at length. One of his conclusions is that all quotations by Alexander of Aphrodisias could derive from Philoponus' commentary on the Physics; ${ }^{43}$ similar results were obtained for Themistius. ${ }^{44}$

(b) Gerhard Endress identified the comments of John the Grammarian as well as those ascribed to Yahyā Ibn 'Adī, and he realized that John Philoponus was the

40 Wilferd Madelung, 'Abû l-Ḥusayn al-Bașrī, Muhammad Ibn 'Alī', in The Encyclopaedia of Islam. New Edition. Supplement, Leiden: Brill, 1980, pp. 25-26.

41 Elias Giannakis, 'The Structure of Abū l-Ḥusayn al-Bașrỉs Copy of Aristotle's Physics', Zeitschrift für Geschichte der Arabisch-Islamischen Wissenschaften 8 (1993), p. 252.

42 Emilio Platti, Yahyā Ibn 'Ad̄̄, philosophe chrétien et philosophe arabe: sa théologie de l'Incarnation', Bruxells: Peeters, 1983, pp. 28-29.

43 Giannakis, Philoponus in the Arabic Tradition, pp. 75-80.

44 Ibid., pp. 132-135. 
author of many of the latter. ${ }^{45}$ Philoponus was eclipsed by the Christian Arab thinker who founded his own school in Baghdad. Yahyā Ibn 'Adī was no longer dependent on the favor of the caliphs whose power had diminished ${ }^{46}$ and he was able to create a school that would last after his death and would be known as the Baghdadi Aristotelians.

(c) Arzanov and Arnzen highlighted the great importance that Syriac texts enjoyed in the school of Yahyā, and they point to two colophons of Arabic translations of Aristotle which confirm the use of Syriac versions of the texts. The first colophon belongs to the translation of the Organon and is preserved in the manuscript Paris, Bibliothèque nationale de France, Arabe 2346; the second is found in this manuscript, at the end of Book I and has been translated above: 'Yahyā Ibn 'Adī (...) collationed it three times, and even a fourth time when he collationed it with the Syriac text (bi-l-suryānî̀)'. Arzanov and Arnzen have painstakingly recorded the passages of the Leiden manuscript where a Syriac source is recognized. They have observed, for instance, that one third of the glosses with Syriac origin are found in commentaries on Book VII, and there are motives for this profusion, as we will see. In regard to the initial account in this presentation:

Treatise on the Hearing of the Physics. With the commentary by Alexander [of Aphrodisias], eight books. Muhammad Ibn Ishāq [Ibn al-Nadīm] says that following commentaries by Alexander [of Aphrodisias] ...

the authors have credibly argued that there was a Syriac version of it, although modified and not literal, which should have fostered the Arab interest in the Aristotelian Physics. ${ }^{47}$ The Leiden manuscript therefore witnesses not only the influence and liveliness of the Baghdadi Aristotelians but also the forgotten Syriac tradition. No matter how valuable such historical elements are, our core interest is the Physics of Aristotle itself and its Arabic translation and, since the only translation available is Ishāa's, his endeavor will now be the object of our study.

III

Omne quod movetur necesse est ab aliquo moveri are the Latin words translating the proposition with which Aristotle begins Book VII: 'Everything that is in motion must be moved by something' (241b34-241b24). Book VI is one of the places in

45 Gerhard Endress, The Works of Yahyā Ibn 'Adī, Wiesbaden: Reichert Verlag, 1977, pp. 36-37.

46 Mohd Nasir Bin Omar, 'The Life of Yahya Ibn 'Adi: A Famous Christian Philosopher of Baghdad', Mediterranean Journal of Social Sciences 6 (2015), pp. 307-314.

47 Arnzen and Arzhanov, 'Die Glossen in Ms. Leyden Or. 583'. 
Aristotle, his Course on Natural Philosophy and the Arabic Tradition

Aristotle where this principle is discussed, a principle which has theological implications ${ }^{48}$ but is also related to the problem of inertia and medieval discussions on projectile motion. ${ }^{49}$

However the affirmation in this place that 'Everything that is in motion must be moved by something' (241b34) does not seem to be related to the arguments of Book VI, where Aristotle concluded that 'No motion can be infinite in respect of the time that it occupies, with the single exception of circular locomotion'.

Indeed, this book raises difficulties in regard to its content as well as to its codicological tradition. In 1841, Leonhard von Spengel analyzed the Greek manuscripts, read what the Ancient and Renaissance commentators had written on the issue, and described the two versions for the first three chapters of the book, one as the one generally accepted, and the other, widely disputed since

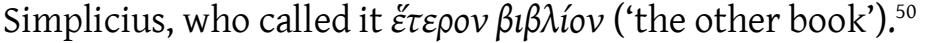

Concerning its content, W. David Ross considered the various aspects and asserted: 'Book VII does stand outside the main structure of the Physics. Books V, VI and VIII form a unity which it interrupts' ${ }^{51}$ Book VII is of an earlier date, as Simplicius had already sustained. ${ }^{52}$

Robert Wardy does not agree with most of the scholars and claims that 'Book VII.1's proof (deepened and clarified by the discussion of VII.2-5) legitimates the argument of VIII.1. ${ }^{53}$ There is also disagreement regarding the respective value or version $\alpha$ and $\beta$ : while many scholars see $\alpha$ as the original work of Aristotle and $\beta$ as a remake of $\alpha$, Wardy asserts that the two are of equal value or at least that the $\varepsilon^{\tau} \tau \varepsilon \rho o v \beta i \beta \lambda i o v$ is 'the response of an early Peripatetic student to his reading of $\alpha^{\prime} .^{54}$ Wardy's views have not gone uncontested and Thomas Olshewsky has objected to both tenets with good arguments. ${ }^{55}$

The relevant fact is that Ishāq Ibn Hunayn relied on a text closer to $\beta$-version for his translation. Averroes (d. 1198) read this translation, as we can see in the

48 James A., Weisheipl, 'The Principle Omne quod movetur ab alio movetur in Medieval Physics', Isis 56 (1965), pp. 26-46.

49 André Goddu, The Physics of William of Ockham, Leiden: Brill 1984, pp. 193-205.

50 Leonhard von Spengel, 'Über das siebente Buch der Physik des Aristoteles', Abhandlungen der philosophisch-philologischen Classe der Königlichen Bayerischen Akademie der Wissenschaften, 1841, pp. 305-349.

51 W. David Ross (ed.), Aristotle's Physics, Oxford: Oxford UP, 1936, p. 17.

52 Simplicius, On Aristotle's Physics 7, trans. Michael Hagen, London: Duckworth, 1994, p. 11.

53 Robert Wardy, The Chain of Change: A Study of Aristotle's Physics VII, Cambridge: Cambridge University Press, 1990, p. 89.

$54 \quad$ Ibid., p. 249.

55 Thomas M. Olshewsky, 'Self-Movers and Unmoved Movers in Aristotle's Physics VII', The Classical Quarterly, New Series 45/2 (1995), pp. 389-406. 
printed editions of Michael Scotus' translation from Arabic into Latin ${ }^{56}$, and Thomas Aquinas relied also on $\beta$-version. ${ }^{57}$

(a) Ishāq's vocabulary has well defined technical terms as we see in the sample and also through all the translation of the Physics. Motion and derivative terms abound in the book and they are consistently translated, as we can see in the

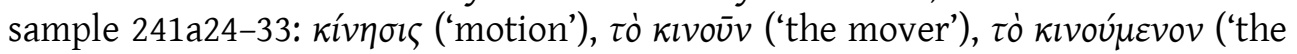

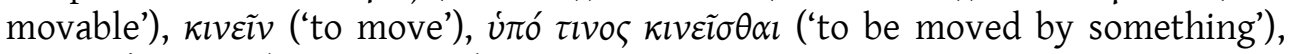
$\sigma \tau \tilde{\eta} v \alpha l$ / $\hat{\rho}_{\rho \mu \varepsilon \varepsilon \tilde{i} v}$ ('to be at rest').

Ishāa Ibn Ḥunayn uses following terms:

kivnolৎ is built with the suffix $\sigma l^{-}$, a suffix expressing an abstract meaning. ${ }^{58}$ The Arabic translation uses the mașdar form haraka. Mașdar means literally the source of all forms, verbal as well as nominal, deriving from a semantical root.

KIVEĩ is active and transitive: 'to cause motion.' The Arabic finds its way to express this transitive aspect using the intensive form fa" ala from the derived forms: harraka.

vió $\tau \imath v 0 \varsigma \kappa \imath v \varepsilon \tilde{\imath} \sigma \theta \alpha l$ is in the passive voice with the agent in the prepositional genitive. The Arabic has a passive voice which, however, excludes the agent and for this reason is called the unknown, majhūl. Since the translator was well aware of the need to point to the agent he found the solution again in the derived forms: in the form tafa" ala, taharraka, which is the reflexive construction of the fa" ala form, and in the use of the particle 'an denoting origin, reference or cause for the agent.

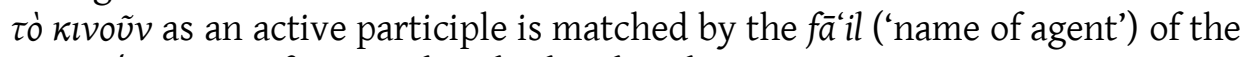
intensive/causative form: muharrik, al-muharrik.

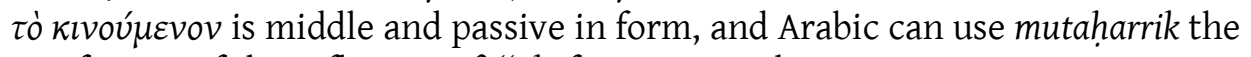
name of agent of the reflexive tafa "ala form to translate it.

$\tau \dot{o} \sigma \tau \tilde{\eta} v \alpha l$, and $\tau \dot{o} \eta \dot{\eta} \rho \varepsilon \varepsilon \tilde{\mathcal{V}} v$, in the substantiated infinitive mood, are translated by the so called 'name of origin' mașdar, here: wuqūf. The pattern fu'ül belongs to verbs of motion.

(b) As for the way on how complex sentences and chains of reasoning are translated here, follow the first five paragraphs:

\section{$\S 1$}

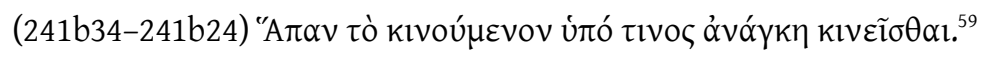

56 Averroes, Aristotelis De Physico Auditu libri octo cum Averrois Cordubensis variis in eosdem commentariis. Quartum Volumen. Venice: Apud Iunctas, 1562, 305 M-306 A.

57 Olshewsky, 'Self-Movers and Unmoved Movers', p. 392.

58 Herbert Weir Smyth, A Greek Grammar for Colleges, New York: American Book Company, 1920, n. 865. 
Aristotle, his Course on Natural Philosophy and the Arabic Tradition

Everything that is in motion must be moved by something. ${ }^{60}$

$$
\text { كل متحرك فواجب ضرورة أن يكون يتحرك عن شيء ما. }
$$

Every movable must necessarily move because of something. ${ }^{61}$

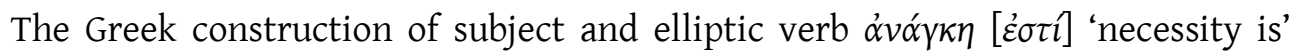
requiring an infinitive form is reformulated into a construction where the subordinate clause becomes the subject of the main one, the predicate of which is a participle wājib ${ }^{u n}$ ('binding') accompanied by an adverb, darūrat ${ }^{a n}$ ('necessarily') intensifying the sense.

Shay'um $m \bar{a}$ (literally, 'a certain thing') is the periphrasis of an inexistent indefinite pronoun in Arabic.

\section{$\S 2$}

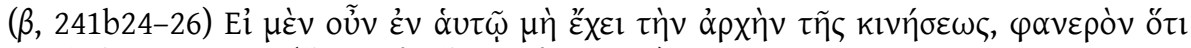

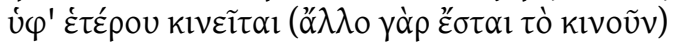

For if it has not the source of its motion in itself it is evident that it is moved by something other than itself, for there must be something else that moves it.

$$
\text { فأما إن لم يكن مبدأ حركنه فيه فظاهر أنه إنما يتحرك عن شيء آخروذلك أن المحرك له يكون غيره. }
$$

For if the principle of its motion is not in it[self], it is evident that it moves by the action of something else (another thing), because what moves it (its mover) will be another. $^{62}$

The conditionals are parallel in both languages: In Greek, the protasis uses the indicative present, and the protasis the indicative future, in Arabic, the protasis uses the jussive mood because the sentence is negative, and the apodosis, yakūnu, the imperfect of kāna in order to render है $\sigma \tau \alpha l$.

Greek particles are very difficult to translate, oũv becomes - $-1, f a-$. The opposition $\mu \dot{\varepsilon} v-\delta \varepsilon$ is approximately وأما - أما .

\section{$\S 3$}

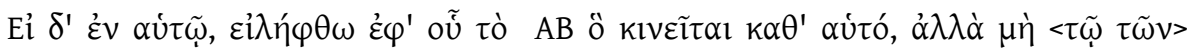

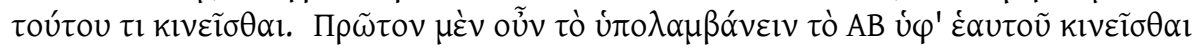

59 The text is reproduced according to Wardy's edition.

60 Aristotle, Physics, trans. R. P. Hardie and R. K. Gaye (ed. by Jonathan Barnes, The Complete Works of Aristotle, vol. I, Princeton: Princeton UP 1984). URL $=<$ http://classics.mit.edu/Aristotle/physics. html (Accessed June 2017).

61 MS Leiden, fol. 185v.4; Cf. Al-Tabita, p. 733.

62 MS Leiden, fol. 185v.4-6; Cf. Al-Tabîa, p. 733. 


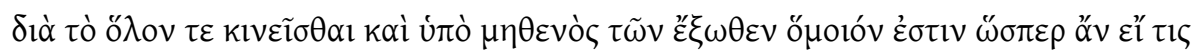

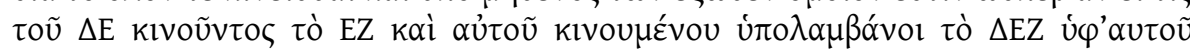

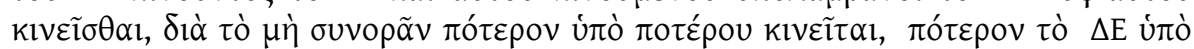

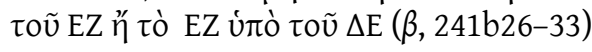

I reproduce Wardy's translation of version $\beta$ as well as Hardie and Gaye's, who follow version $\alpha$ :

If alternatively it does have the origin of change in itself, take an object $A B$ that is changed per se and not by one of its parts being changed. First, to suppose that $A B$ is changed by itself on the grounds that it is changed as a whole and that it is changed by nothing external to it is similar to the case in which, should DE change $\mathrm{EF}$ and itself be changing, someone were to suppose that DEF is changed by itself, on the grounds that he could no detect which is changed by which, whether DE is changed by EF or EF by DE ( $\beta$, Wardy). ${ }^{63}$

If on the other hand it has the source of its motion in itself, let $A B$ be taken to represent that which is in motion of itself and not in virtue of the fact that something belonging to it is in motion. Now in the first place to assume that $A B$, because it is in motion as a whole and is not moved by anything external to itself, is therefore moved by itself -this is just as if, supposing that KL is moving LM and is also itself in motion, we were to deny that KM is moved by anything on the ground that it is not evident which is the part that is moving it and which the part that is moved ( $\alpha$, Hardie and Gaye).

$$
\begin{aligned}
& \text { وأما إن كان مبدأ حركته فيه فلنأخذ" الذي عليه أب حتى يكون يتحرك لا من ** قبل أن شيئاً مثنه }
\end{aligned}
$$

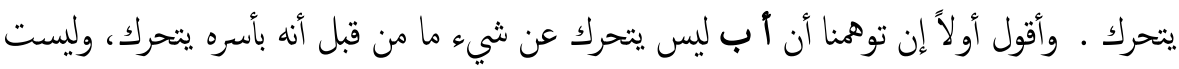

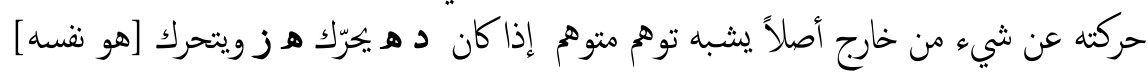

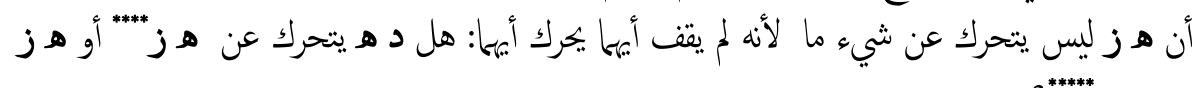

$$
\begin{aligned}
& \text { عن د هـ }
\end{aligned}
$$

Or, if the principle of its motion is in itself, let us take* which is to represent $A B$ so that it does not** move by one*** of its parts moving. First, I say that if we suppose that $A B$ does not move because of something by moving as a whole, and that its motion is not at all by anything external, this is similar to if someone were to suppose that if DE moves EZ and [itself] is moving, EZ does not move because of something for the reason that one could not verify which moves which, whether $\mathrm{DE}$ moves because of $\mathrm{EZ}$ or $\mathrm{EZ}^{* * * *}$ because of $\mathrm{DE}^{* * * * *} ?^{64}$

63 Wardy, The Chain of Change, 1990, p. 41.

${ }_{64}$ MS Leiden, fol. 185v.6-9; Cf. Al-Ṭabita, pp. 733-734. 
Aristotle, his Course on Natural Philosophy and the Arabic Tradition

[هو نفسة][itself] is inserted by Badawi. The stars * refer to five marginal notes in the manuscript marked by different sigla. Badawi read and printed them, but none of them corrects 'that EZ does not move' with 'that DEZ does not move'; Badawi corrected it introducing the Greek text. One of the marginal notes, $\mathrm{EZ}^{* * * *}$, is a textual variant related to Yahyā Ibn 'Adī who could have seen another translation because the copyist added: 'In the copy of Ibn 'Adī aw 'an DM, and there is not $H Z^{\prime} .^{65}$

(i) As for the technique of translation we observe that the passive perfect imperative $\varepsilon^{i} \lambda \dot{\eta} \varphi \theta \omega$, with a present meaning is rendered with a personal form, the jussive of akhadha ( $\lambda \alpha \mu \beta \alpha \dot{\alpha} v \omega)$ preceded by the particle $f a-l$ ('let us take').

(ii) Further, $v \pi$ in $\alpha \mu \beta \alpha \dot{v \varepsilon v v}$ is translated as tawahhama which is closer to

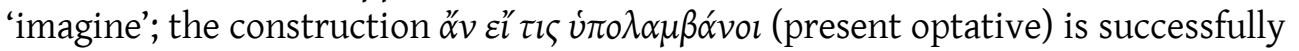
converted into tawahhum ${ }^{u}$ mutawahhim ${ }^{\text {in }}$, literally 'the supposition of someone who supposes'.

(iii) In Greek the genitive absolute expresses a rich variety of circumstances such as time, cause, condition, concern, etc. Since Arabic does not have this construction, the translators had to figure out its equivalent. Both genitive

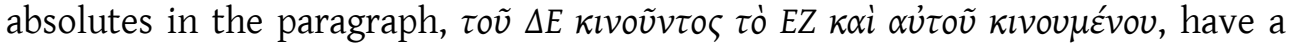
conditional character. Ishāq built with idhā a conditional period 'if DE moves EZ and itself is moving'.

(iv) Greek particles always raise difficulties. The contrastive $\mu \dot{\varepsilon} v-\delta \varepsilon$ is often neglected. The particle ouvv modifies $\pi \rho \tilde{\omega} \tau o v$ and the translator may have echoed it when he wrote 'First, I say'.

(v) Greater difficulties arise from the Greek syntax and its concentric way of subordinated sentences. The Greek article with the infinitive mood is used to

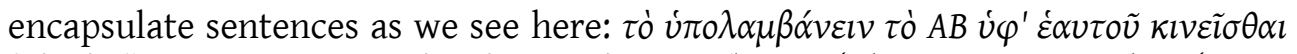

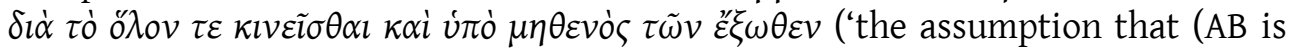
moved by itself) because the whole is moved and that it is not moved by anything external to itself).

The Arabic equivalent to the Greek article, al-, does not have this capacity and it is basically a determinant particle. On the other side, the equivalent to the infinitive mood, the mașdar, is more limited. The underlying issue is that Greek has a concentric syntax while Arabic, a lineal one.

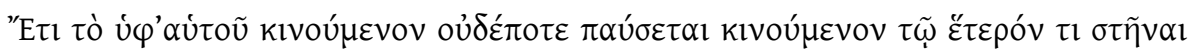

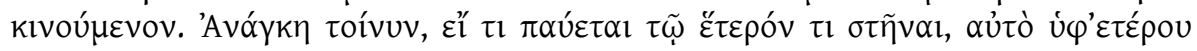

${ }_{65}$ MS Leiden, fol. 185v.10, marg.; Cf. Al-Ṭabta a, p. 734, n. 2. 


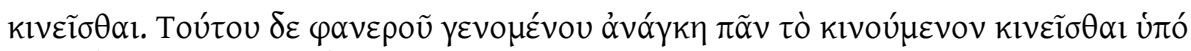

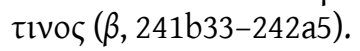

Again, something changed by itself will never cease from changing as a consequence of another thing's having stopped changing. Accordingly it is necessary, if anything ceases from changing as a consequence of another thing's having stopped, that it is changing by something other than itself. Once this becomes evident, then it is necessary that everything that is changed is changed by something (version $\beta$, Wardy).

In the second place that which is in motion without being moved by anything does not necessarily cease from its motion because something else is at rest, but a thing must be moved by something if the fact of something else having ceased from its motion causes it to be at rest. Thus, if this is accepted, everything that is in motion must be moved by something (version $\alpha$, Hardie and Gaye).

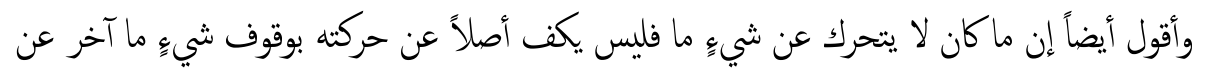

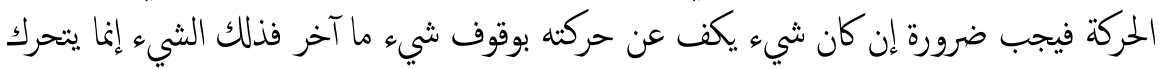

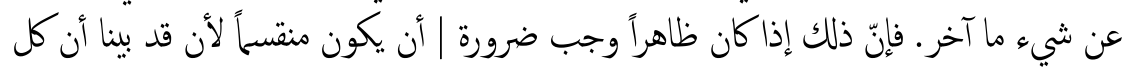

$$
\begin{aligned}
& \text { متحرك فنقسم. }
\end{aligned}
$$

Again, I say that if that which does not move because of something does not cease from its motion at all by something else ceasing from its motion. It necessarily must [follow] if something ceases from motion by something else ceasing from its motion, such thing moves because of something else. Therefore, if this has become evident it must necessarily be divisible because we have proved that every movable is divisible. ${ }^{6}$

Badawi inserted where there is the mark |:

$$
\text { أن يتحرك عن شيء ما. لأنه إذا فرض أن أب يتحرك فلا بدّ }
$$

and of course, he indicated the insertion. He introduces the sentence 'that it is changed by something because if it is assumed that $A B$ is moved, it must' after 'it must necessarily'. However, the Leiden manuscript is clear and does not have it. Wardy gives one manuscript with a similar reading in his apparatus, although not exactly identical: MS Paris, Bibliothèque nationale de France, Gr. 1853, a very old manuscript. Averroes read: Quoniam, hoc si fuerit manifestum, necesse erit quod omne motum, cum sit divisibile, moueatur ab aliquo ('Because, if this were evident, it would be necessary that every movable is moved by another as it is divisible') and he never could have read the Leiden manuscript. ${ }^{67}$

\footnotetext{
${ }^{66}$ MS Leiden, fol. 185v.10-13; Cf. Al-Ṭabĩa, p. 734.

${ }^{67}$ Averroes, Aristotelis De Physico Auditu, 306 M.
} 
Aristotle, his Course on Natural Philosophy and the Arabic Tradition

(i) Since the article in Arabic does not have the capacity to create a substantive clause the verb of which is an infinitive or a participle, if the Greek

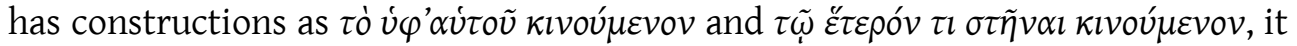
has to render them by other ways. The first syntagma is not found in Ishāq who

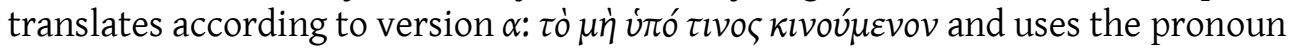

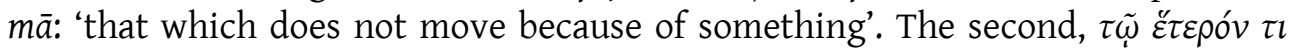

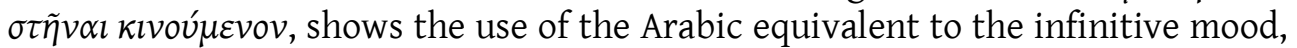
i.e., the mașdar word wuqu $f$ and it makes it similar.

(ii) Ishạq Ibn Ḥunayn estimated a conditional meaning in the absolute

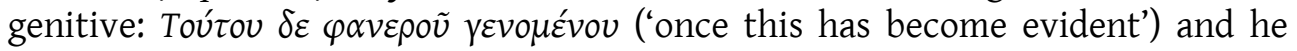
translated it as a protasis: inna dhalika idhā kāna zăhiran.

(iii) For the conditional sentences, the middle present tense $\varepsilon i$ $\tau \imath ~ \pi \alpha u ́ \varepsilon \tau \alpha l$, in the protasis, is translated with a periphrasis of kāna, in kāna yakuffu, that is not frequent but it is admissible. ${ }^{68}$ The clause in the former paragraph, inna dhalika idhā kāna zāhir ${ }^{a n}$, shows another use of kāna to express үí $\gamma v o u \alpha l$.

(iv) Yajibu darurat ${ }^{a n}$ and wajaba darurat $t^{a n}$ are verbal forms with meaning similar to the participle wajjib ${ }^{\text {un }}$ 'binding' darurat ${ }^{a n}$ that has been explained before.

The long tradition of study of Aristotle's works and, and of the Physics in particular, should not lead us to underestimate the task of the translators. We have to assume that the Greek manuscripts they could read were riddled with errors and they were aware of it. They tried to go as close as possible to the original sources and they were faithful to them. Once the text was understood, they had to overcome lexical and syntactical difficulties, and they succeeded. By coining new terms they created a philosophical vocabulary and while struggling with the Greek syntax, they developed an argumentative discourse that enriched the Arabic culture. The examples taken here should show their success and we should be grateful to their effort.

\section{Bibliography}

Arisțūṭālīs, Al-Ṭabĩa, ed. 'Abd-ar-Raḥmān Badawi, Cairo: Al-Hay'a al-Miṣrīya al'Āmma li-l-Kitāb, 1965.

Arnzen, Rüdiger and Arzhanov, Yury, 'Die Glossen in Ms. Leyden Or. 583 und die syrische Rezeption der aristotelischen Physik', in Elisa Coda and Cecilia Martini Bonadeo (eds), De l'antiquité tardive au Moyen Âge: études de logique aristotélicienne et

68 William Wright, A Grammar of the Arabic Language, $3^{\text {rd }}$ ed., Cambridge: Cambridge UP, 1896, vol. II, p. 16 C. 
de philosophie grecque, syriaque, arabe et latine offertes à Henri Hugonnard-Roche, Paris: Vrin, 2014, pp. 415-464.

Averroes, Aristotelis De Physico Auditu libri octo cum Averrois Cordubensis variis in eosdem commentariis. Quartum Volumen. Venice: Apud Iunctas, 1562.

- Commentarium Magnum in Aristotelis Physicorum Librum Septimum (Vindobonensis, lat. 2334), ed. Horst Schmieja, Paderborn: Schöningh, 2007.

Bosworth, Clifford Edmund, 'The Political and Dynastic History of the Iranian World (1000-1217)', in John Andrew Boyle (ed.), The Cambridge History of Iran, Cambridge: Cambridge University Press, 1968, pp. 119-124.

De Jong, Pieter and de Goeje, Michael Jan, Catalogus codicum orientalium bibliothecae Academiae Lugduno Batavae, vol. III, Leiden: Brill, 1865.

Endress, Gerhard, The Works of Yahȳā Ibn 'Ad̄̄, Wiesbaden: Reichert Verlag, 1977.

Giannakis, Elias. Philoponus in the Arabic Tradition of Aristotle's Physics, Oxford: British Thesis Service, 1992.

- 'The Structure of Abū l-Husayn al-Bașrī’s Copy of Aristotle's Physics', Zeitschrift für Geschichte der Arabisch-Islamischen Wissenschaften 8 (1993), pp. 251-258.

Goddu, André, The Physics of William of Ockham, Leiden: Brill, 1984.

Ibn al-Nadīm, Abū l-Faraj Muhammad, The Fihrist of al-Nadìm, trans. Bayard Dodge, New York: Columbia University, 1970.

- Kitāb al-Fihrist li-l-Nadìm, ed. Reza Tajaddud, Teheran: Marvi Offset Printing, 1971.

Kaḥhāla, 'Umar Rịḍa, Mújam al-mu'allifin, 4 vols, Beirut: Mu'assasat al-Risāla, 1994, vol. II.

Madelung, Wilferd, 'Abû l-Ḥusayn al-Bașrī, Muhammad Ibn 'Alī', in The Encyclopaedia of Islam. New Edition. Supplement, Leiden: Brill, 1980, pp. 25-26.

Olshewsky, Thomas M., 'Self-Movers and Unmoved Movers in Aristotle's Physics VII’, The Classical Quarterly, New Series 45/2 (1995), pp. 389-406.

Omar, Mohd Nasir Bin, 'The Life of Yahya Ibn 'Adi: A Famous Christian Philosopher of Baghdad', Mediterranean Journal of Social Sciences 6 (2015), pp. 307314.

Peters, Francis, Aristoteles Arabus: The Oriental Translations and Commentaries of the Aristotelian Corpus, Leiden: Brill, 1968.

Platti, Emilio, Yahyā Ibn 'Ad̄̄, philosophe chrétien et philosophe arabe: sa théologie de l'Incarnation', Bruxells: Peeters, 1983. 
Qifțī, 'Alī Ibn Yūsuf al-, Ta'rīkh al-Hukamā', ed. Julius Lippert and August Müller, Leipzig: Dieterich'sche Verlagsbuchhandlung, 1903.

Ross, W. David (ed.), Aristotle's Physics, Oxford: Oxford UP, 1936.

Simplicius, On Aristotle's Physics 7, trans. Michael Hagen, London: Duckworth, 1994.

Smyth, Herbert Weir, A Greek Grammar for Colleges, New York: American Book Company, 1920.

Spengel, Leonhard von, 'Über das siebente Buch der Physik des Aristoteles', Abhandlungen der philosophisch-philologischen Classe der Königlichen Bayerischen Akademie der Wissenschaften, 1841, pp. 305-349.

Stern, Samuel Miklos, 'Ibn al-Samh', The Journal of the Royal Asiatic Society of Great Britain and Ireland 1/2 (1956), pp. 31-44.

Wardy, Robert, The Chain of Change: A Study of Aristotle's Physics VII, Cambridge: Cambridge University Press, 1990.

Weisheipl, James A., 'The Principle Omne quod movetur ab alio movetur in Medieval Physics', Isis 56 (1965), pp. 26-46.

Wright, William, A Grammar of the Arabic Language, $3^{\text {rd }}$ ed., Cambridge: Cambridge UP, 1896. 